\title{
Penerapan Lesson Study Pada Tema Lingkungan Sahabat Kita Subtema Usaha Pelestarian Lingkungan Pembelajaran
} 2

\section{Endang Herlindawati ${ }^{1}$, Ny. Kusmariyatni ${ }^{2}$, Kt. Wiryawati ${ }^{3}$}

${ }^{12}$ Jurusan Pendidikan Bahasa Inggris Universitas Pendidikan Ganesha

\section{ART I C L E I N F O}

Article history:

Received January 21, 202

Revised February 03, 2021

Accepted April 08, 2021

Available online May 25, 2021

Kata Kunci:

Lesson study, Aktivitas Siswa.

Keywords:

Lesson study, Student Activities.

\begin{abstract}
A B S T R A K
Praktik pembelajaran konvensional cenderung menekankan pada bagaimana guru mengajar dari pada siswa belajar, dan secara keseluruhan hasilnya tidak banyak memberikan kontribusi bagi peningkatan mutu proses dan hasil pembelajaran siswa. Lesson Study merupakan alternatif yang berguna untuk mengatasi masalah praktik pembelajaran yang selama ini dipandang kurang efektif. Adapun tahapan-tahapan dalam Lesson Study yaitu: (1) Perencanaan (Plan); (2) Pelaksanaan (Do); (3) Refleksi (See). Dalam hal ini, Lesson Study dapat dijadikan sebagai salah satu alternatif guna mendorong terjadinya perubahan dalam praktik pembelajaran yang dilakukan di Kelas V SD Negeri 3 Banjar Jawa Semester II Tahun Ajaran 2018/ 2019 ke arah yang lebih efektif.Fokus yang paling utama dari Lesson Study adalah pengembangan dan pembelajaran yang dilakukan siswa, misalnya apakah siswa menunjukkan minat dan motivasinya dalam belajar, bagaimana siswa bekerja dalam kelompok kecil, bagaimana siswa melakukan tugas-tugas yang diberikan guru, serta hal-hal lainya yang berkaitan dengan aktivitas, partisipasi, serta kondisi dari setiap siswa dalam mengikuti setiap pembelajaran. Dengan demikian, pusat perhatian tidak lagi hanya tertuju pada bagaimana cara guru dalam mengajar sebagaimana lazimnya dalam sebuah supervisi kelas yang dilaksanakan oleh kepala
\end{abstract} sekolah atau pengawas sekolah.

\begin{abstract}
A B S T R A C T
Conventional learning practices emphasize the way teachers teach students to learn, and all results do not contribute to improving the quality of students' learning processes and outcomes. Lesson Study is a useful alternative to overcome the problem of learning practices that have so far been less effective. The stages in Lesson Study are: (1) Planning (Plan); (2) Implementation (Do); (3) Reflection (See). In this case, Lesson Study can be used as an alternative to encourage changes in learning practices carried out in Class V of SD Negeri 3 Banjar Jawa Semester II Academic Year 2018/2019 to a more effective direction. The most important focus of Study Lessons is the development and learning of students, for example students who are interested and motivated in learning, how students work in small groups, how students perform tasks assigned by the teacher, and other things provided with activities, participation, and from each student in participating in each lesson. Thus, the center of attention is no longer just discussing the way the teacher in teaching asks normally in the supervision class conducted by the principal or school supervisor.
\end{abstract}

\section{Pendahuluan}

Menurut Undang-Undang No. 20 Tahun 2003 pendidikan nasional berfungsi mengembangkan kemampuan dan membentuk watak serta peradaban bangsa yang bermartabat dalam rangka mencerdaskan kehidupan bangsa, bertujuan untuk berkembangnya potensi siswa agar menjadi manusia yang beriman dan bertaqwa kepada Tuhan Yang Maha Esa, berakhlak mulia, sehat, berilmu, cakap, kreatif, mandiri dan menjadi warga negara yang demokratis serta bertanggung jawab (Wardana, 2020). Pendidikan adalah suatu usaha sadar danterencana untuk mewujudkan suasana belaja dan proses pembelajaran agar peserta didik dapat aktif mengembangkan potensinya. Sekolahmerupakan lembaga formal yang berfungsi membantukhususnya orang tua dalam memberikanpendidikan kepada anak-anak mereka. Pendidikan memberikan pengetahuan, keterampilan dan sikap kepada anak didiknya secara lengkap sesuai dengan yang mereka butuhkan. Pemerintah telah menetapkan Undang-undang Nomor 20 Tahun 2003 tentang Sistem Pendidikan Nasional. Dalam UU tersebut SPN terdapat beberapa potensi akademik yang akan dikembangkan, dimana potensi tersebut berkaitan dengan karakter. Hal tersebut dijabarkan dalam pasal 3 UU SPN bahwa "Pendidikan nasional berfungsi mengembangkan kemampuan dan membentuk watak serta peradaban bangsa yang bermartabat dalam rangka mencerdaskan kehidupan bangsa, bertujuan untuk berkembangnya potensi peserta didik agar menjadi manusia yang beriman dan bertakwa kepada Tuhan Yang Maha Esa, berakhlak mulia, sehat, berilmu, cakap, kreatif, mandiri, dan menjadi warga negara yang demokratis serta bertanggung jawab" (Indriati, 2012).

Copyright (C) Universitas Pendidikan Ganesha. All rights reserved. 
Pendidikan merupakan sarana yang penting dalam menciptakan Sumber Daya Manusia (SDM) yang berkualitas. SDM yang berkualitas dapat terbentuk apabila menerapkan pendidikan sebagai kunci utama dari perkembangan ilmu dan teknologi. Pendidikan merupakan suatu proses komunikasi yang di dalamnya mengandung transformasi pengetahuan, nilai-nilai dan keterampilan-keterampilan, di dalam dan di luar sekolah yang berlangsung sepanjang hayat (life long education), dari generasi ke generasi (Dwi Siswoyo, 2008: 25). Suryati Sidharto (dalam Dwi Siswoyo, 2008: 146-147) mengatakan bahwa pendidikan telah berlangsung sejak dulu hingga sekarang. pendidikan yang dimaksud adalah apa yang dilakukan oleh orang dewasa atau orang tua dalam mengajarkan anaknya cara hidup sehari hari, agar dikemudian hari anak dapat hidup dengan baik tanpa suatu kesulitan. Pendidikan tidak hanya diperoleh di (Novianti, 2020).

Pembelajaran pada hakikatnya merupakan proses interaksi antara peserta didik dengan lingkungannya, sehingga terjadi perubahan perilaku kearah yang lebih baik (Mulyasa, 2010). Proses pembelajaran sepenuhnya diarahkan pada pengembangan pada ranah kognitif, afektif, dan psikomotor secara utuh/holistik. Dengan demikian proses pembelajaran secara utuh melahirkan kualitas yang mencerminkan keutuhan penguasaan sikap, pengetahuan, dan

keterampilan (Depdiknas, 2013).Pencapaian tujuan pembelajaran ini dapat ditentukan oleh adanya motivasi peserta didik untuk berubah menjadi lebih baik (Syamsiara Nur, 2017).

Indeks pembangunan manusia atau HDI (Human Development Index) tahun 2018 menunjukkan bahwa Indonesia berada pada rangking 116, sedangkan Malaysia pada posisi 57 dan Singapura berada pada posisi 57 dari 189 negara. Rangking Indonesia pada pengukuran perbandingan melek huruf, pendidikan dan standar hidup masih jauh dari negara tetangga. Hal ini terjadi karena adanya kesenjangan antara regulasi atau peraturan atau undang-undang dengan realita praktik pendidikan di Indonesia.Menurut Undang-Undang No 20 Tahun 2003 tentang sistem pendidikan nasional, yang dimaksudpendidikan adalah usaha sadar dan terencana untuk mewujudkan suasana belajar dan proses pembelajaran agar peserta didik secara aktif mengembangkan potensi dirinya untuk memiliki kekuata spiritual keagamaan, pengendalian diri, kepri- badian, kecerdasan, akhlak mulia, serta keterampilan yang diperlukan dirinya. Pendidikan nasional bertujuan untuk mengembangkan potensi peserta didik agar menjadi manusia yang beriman dan bertaqwa kepada Tuhan Yang Maha Esa, berkhlak mulia, sehat, berilmu, cakap, kreatif, mandiri, dan menjadi warga negara yang demokratis serta bertanggung jawab. Secara teoritik keberhasilan pendi- dikan secara utuh memerlukan proses panjang, mulai dari kajianberbagai gagasan tentang pengembangan desain kurikulum, penyiapan dan penugasan pendidik dan tenaga kependidikan, penyediaan sarana dan prasarana, penyiapan tata kelola pelaksanaan kurikulum, pembelajaran, dan penilaian. Berdasarkan Undang-Undang No 19 Tahun 2005 tentang standar nasional pendidikan, bahwa proses pembelajaran harus interaktif, inspiratif, menyenangkan, menantang, memotivasi untuk aktif, kreatif, mandiri sesuai bakat, minat dan perkembangan fisik dan psikologi peserta didik. Keberhasilan proses pembelajaran bergantung pada kualitas guru atau pendidik yang profesional dan kompeten. Menurut Sadirman A.M. (2004:165), guru yang kompeten adalah guru yang mampu mengelola program belajar-mengajar. Mengelola di sisi memiliki arti yang luas yang menyangkut bagaimana seorang guru mampu menguasai keterampilan dasar mengajar, seperti membuka dan menutup pelajaran, menjelaskan, memvariasi media, bertanya, memberi penguatan, dan sebagainya, juga begaimana guru menerapkan strategi, teori belajar dan pembelajaran, dan melaksanakan pembelajaran kondusif.

Menurut Undang-Undang No 15 Tahun 2005 tentang guru dan dosen, bahwa pengakuan terhadap guru dan dosen sebagai tenaga profesional akan diberikan manakala guru atau dosen telah memiliki kualifikasi akademik, kompetensi, dan sertifikat pendidik yang diper- syaratkan. Pemerintah berupaya mem- perbaiki kualitas pendidikan dengan program profesi guru serta pendampingan kurikulum 2013 yang bertujuan untuk memberikan penguatan dalam pelak- sanaan kurikulum di sekolah. Selain itu, FKIP selaku Lembaga Pencipta Tenaga Kependidikan (LPTK) diharapkan mampu menciptakan kualitas guru yang lebih baik. Salah satu caranya yaitu dengan praktik Lesson Study (LS) yang sudah lama pernah dilaksanakan di negara Jepang dengan hasil yang berkesinambungan dan berkelanjutan sebagai upaya mening- katkan kapasitas dan kompetensi calon tenaga pendidik.

Praktik pelaksanaan Lesson Study (LS) bagi pendidikan di Indonesia merupakan hal baru yang belum membudaya dikalangan guru. Lesson Study (LS) adalah salah satu pendekatan analisis kasus pada praktek pembelajaran, ditujukan untuk membantu pengembangan profesionalisme para guru dan membuka kesempatan bagi mereka untuk saling belajar berdasarkan praktek-praktek nyata di kelas. Lesson Study (LS) adalah suatu model pembinaan profesi pendidik melalui pengkajian pembelajaran secara kolaboratif dan berkelanjutan berlan- daskan asas-asas kolegalitas dan mutual learning untuk membangun komunitas belajar. Dalam kegiatan Lesson Study, dapat memilih dan menerapkan berbagai 
metode/strategi pembelajaran yang sesuai dengan situasi, kondisi, atau perma- salahan yang dihadapi pendidik.

Pelaksanaan Lesson Study, bukan hanya guru yang melaksanakan pembelajaran saja yang dapat memetik manfaat, namun terlebih lagi para observer (guru lain/mitra, mahasiswa, dosen dan pihak-pihak lain) yang hadir pada saat pembelajaran. Dengan mengamati kegiatan pembelajaran yang dilakukan seorang guru, observer didorong untuk merefleksikan pembela- jaran yang dilaksanakannya dan bagaimana meningkatkan kualitasnya. Oleh karena itu, Lesson Study dapat dijadikan sebagai salah satu alternatif guna mendorong terjadinya perubahan dalam praktik pembelajaran di Indonesia menuju ke arah yang jauh lebih efektif.

Berdasarkan penjelasan diatas, Lesson Study tampaknya dapat dijadikan sebagai salah satu alternatif guna mendorong terjadinya perubahan dalam praktik pembelajaran di Indonesia menuju ke arah yang jauh lebih efektif. Dalam hal ini, camon pendidik ataupun pendidik dituntut tidak hanya dapat merencanakan dan melaksanakan kegiatan pembela- jaran, namun juga dapat melaksanakan open class dalam Lesson Study dalam rangka membentuk guru profesional.

Lesson Study merupakan salah satu upaya untuk meningkatkan proses dan hasil pembelajaran yang dilaksanakan secara kolaboratif dan berkelanjutan oleh sekelompok guru. Tujuan utama Lesson Study yaitu: a) Untuk memperoleh pemahaman yang lebih baik tentang bagaimana siswa belajar dan guru mengajar, b) Untuk memperoleh hasil- hasil tertentu yang bermanfaat bagi para guru lainnya dalam melaksanakan pembelajaran, c) Untuk meningkatkan pembelajaran secara sistematis melalui kooperatif AIR (Auditory, Intellectuallity, Repetition), d) Untuk membangun sebuah pengetahuan pedagogis, dimana seorang guru dapat menimba pengetahuan dari guru lainnya. Sedangkan tujuan khusus yang ingin dicapai dalam Lesson Study adalah: a) Untuk mengetahui pelaksanaan Lesson Study di SD Negeri 3 Banjar Jawa pada saat PPL PPG Pendidikan Guru Sekolah Dasar Prajabatan III semester II tahun pelajaran 2018/2019, b) Untuk mengetahui hasil observasi dan refleksi sebagai bahan untuk meningkatkan proses pembelajaran di SD Negeri 3 Banjar Jawa.

\section{Metode}

\section{Rancangan Penelitian}

Lesson Study ini dilaksanakan di kelas VC SD Negeri 3 Banjar Jawa dengan jumlah peserta didik sebanyak 32 orang dengan laki-laki bejumlah 12 orang dan perempuan 20 orang. Waktu Pelaksanaan Lesson Study ini berlangsung pada hari Jumat, 29 Maret 2019, pukul 07.30 WITA - 09.15 WITA. Lesson Study ini dilaksanakan dalam 1 pertemuan, dan melalui tiga tahapan sesuai dengan tahapan yang telah dikeluarkan oleh Indonesia Center for Lesson Study (Sumar Hendayana, 2009: 7-10) yaitu:

\section{a. Tahap Perencanaan (Plan)}

Adapun kegiatanyang direncanakan sebagai berikut yaitu: Menentukan sejauh mana materi yang akan dibahas, Merumuskan indikator pembelajaran berdasarkan Kompetensi Inti (KI), dan Kompetensi Dasar (KD) yang tercantum pada kurikulum 2013, Merumuskan tujuan pembelajaran dari indikator masing-masing kompetensi dasar (KD), Menyusun langkah-langkah pembelajaran,Merancang dan menyiapkan lembar penilaian peserta didik, Menyusun lembar observasi, Merencanakan pembentukan kelompok, Menyusun instrumen tes evaluasi yang akan digunakan untuk mengukur hasil belajar peserta didik.

b. Tahap Pelaksanaan (Do)

Adapun kegiatan yang direncanakan sebagai berikut yaitu: Guru model memberikan denah tempat duduk siswa kepada masing-masing observer, sehingga mudah bagi observer untuk mengenali peserta didik. Selain itu dipermudah dengan memakaikan nomor punggung dan dada pada setiap peserta didik, Guru model membuka pembelajaran dengan memberi salam, Peserta didik.

diminta membentuk 5 kelompok masing- masing kelompok terdiri dari 6-7 peserta didik, Guru model menginformasikan materi yang akan dibelajarkan yaitu materi kualitas air, Obsever berkeliling memeriksa keaktifan peserta didik pada saat pembelajaran berlangsung, Observer mencatat kejadian yang terjadi pada saat proses pembelajaran berlangsung, Mencatat nama peserta didik yang aktif dan tidak aktif, Observer mengobservasi tindakan yang dilakukan guru terhadap anak yang memiliki masalah dalam belajar, Observer berkeliling melihat kegiatan peserta didik, akan tetapi tidak boleh berbicara dengan peserta didik, hanya memantau saja.

\section{c. Tahap Refleksi (See)}

Setelah dilakukan Do, maka ada See, guru model beserta obsever berdiskusi tentang masalah yang terjadi selama kegiatan Do. Observer melaporkan hasil observasi di lapangan, dan memberikan saran yang dapat memperbaiki proses pembelajaran berikutnya. Dalam penelitian ini, penulis menggunakan teknik pengumpulan data antara lain teknik observasi, wawancara, metode tes, serta analisis tes hasil belajar 
Data pelaksanaan Lesson Study diperoleh dengan melakukan pengamatan selama tahap plan berlangsung. Pengamatan dilakukan oleh rekan guru sebagai observer sebanyak 3 orang atau lebih. Observer mengamati bagaimana guru model menguji coba efektivitas model pembelajaran yang telah dirancang. Selanjutnya guru model dan observer akan melakukan diskusi tentang pembelajaran yang telah dilakukan dan pengamat memberi saran dan kritik demi perbaikan pembelajaran. Kegiatan ini dilakukan pada tahap see.

\section{Hasil Dan Pembahasan}

Tahap plan bertujuan untuk menghasilkan rancangan pembelajaran yang diyakini mampu membelajarkan peserta didik secara efektif serta membangkitkan partisipasi aktif peserta didik dalam pembelajaran. Pada tahap ini dilakukan beberapa perencanaan untuk mempersiapkan Lesson Study. Perencanaan yang baik tidak dapat dilakukan secara sendirian. Beberapa pendidik dapat berkolaborasi untukmemperkaya ide terkait dengan rancangan pembelajaran yang akan dihasilkan, baik dalam aspek pengorganisasian, bahan ajar, aspekpedagogis, maupun aspek penyiapan alat bantu pembelajaran. Hari Jumat, 22 Maret 2019 kegiatannya yaitu pembentukan tim Lesson Study; pemilihan guru model dan observer; penentuan waktu pelaksanaan Lesson Study; penentuan tempat yang digunakan untuk Lesson Study yaitu Kelas VC SD Negeri 3 Banjar Jawa; penentuan materi pembelajaran untuk Lesson Study yaitu Tema 8 Subtema 3 Pembelajaran 2 dengan materi Kualitas Air. Senin, 25 Maret 2019, kegiatannya adalah menyusun perangkat pembelajaran yang meliputi RPP, media pembelajaran, dan instrumen penilaian. Menyusun Lembar Observasi Lesson sudy.

Rabu, 27 Maret 2019, kegiatannya adalah konsultasi perangkat pembelajaran yang telah disusun. Konsultasi dilakukan bersama guru Kelas VC, guru pamong, dan Dosen Pembimbing. Jumat, 29 Maret 2019, Pelaksanaan Lesson Study(do). Guru model melaksanakan pembelajaran sesuai rancangan/ skenario yang telah dibuat bersama (plan). Pengamat/observer mengamati dan mengumpulkan informasi mengenai kegiatan belajar peserta didik di lapangan (meliputi aktivitas dalam berpikir, belajar/mempraktikkan, partisipasi, dan berperilaku). Pengkajian mengenai keefektifan pembelajaran yang telah dilakukan dan mencari solusi dari kelemahan pembelajaran (see). Guru model menceritakan pembelajaran yang telah berlangsung di Kelas VC. Pengamat/observer berbagi informasi mengenai pembelajaran yang diamati. Pengamat/observer menggunakan informasi untuk menjelaskan bagaimana peserta didik belajar, berpartisipasi dan berperilaku. Tim Lesson Study bersama- sama mendiskusikan kelebihan dan kelemahan dari pembelajaran yang telah dilaksanakan.

Bersama-sama menyimpulkan hasil dan mengusulkan rekomendasi untuk perbaikan

pembelajaran berikutnya. Pada tahap do terdapat dua kegiatan utama yaitu: 1) Kegiatan pelaksanaan pembelajaran yang dilakukan oleh guru model yang disepakati atau permintaan sendiri untuk memperbaiki RPP yang telah disusun, 2) Kegiatan pengamatan atau observasi yang dilakukan oleh anggota atau komunitas Lesson Study yang lainnya (dosen pembimbing, guru pamong, mahasiswa kolega, atau undangan lainnya yang bertindak sebagai pengamat).

Beberapa hal yang harus diperhatikan dalam tahap do, diantaranya:

Guru melaksanakan pembelajaran sesuai dengan RPP yang telah disusun, 2) Peserta didik diupayakan dapat menjalani pembelajaran dalam setting wajar dan natural, tidak dalam keadaan underpressure disebabkan adanya program Lesson Study dengan adanya observer, 3) Selama kegiatan pembelajaran berlangsung, pengamat tidak diperbolehkan mengganggu jalannya kegiatan pembelajaran dan mengganggu konsentrasi guru maupun peserta didik, 4) Pengamat melakukan pengamatan secara teliti terhadap interaksi antara peserta didik dengan peserta didik, peserta didik dengan bahan ajar, peserta didik dengan guru, peserta didik dengan lingkungan lainnya menggunakan instrumen pengamatan yang telah disiapkan sebelumnya, 5) Pengamat harus dapat belajar dari pembelajaran yang berlangsung dan bukan untuk mengevaluasi guru, 6) Pengamat melakukan pencatatan tentang perilaku belajar peserta didik selama pembelajaran berlangsung, misalnya tentang gerak atau komentar peserta didik dan diusahakan untuk mencantumkan nama kepada peserta didik yang bersangkutan.

Tahap do merupakan tahap pelaksanaan Lesson Study sesuai dengan jadwal yang telah disusun serta dilakukan oleh guru model yang telah ditentukan. Pelaksanaan Lesson Study dilakukan pada hari Jumat, 29 Maret 2019 di kelas VC SD Negeri 3 Banjar Jawa. Pemberian identitas kepada peserta didik juga telah dilaksanakan pada tahap ini.

Tahap see dimaksudkan untuk menemukan kelebihan dan kekurangan pelaksanaan pembelajaran. Tahap ini dilaksanakan pada hari Jumat, 29 Maret 2019. Pada tahap see diawali dengan guru model menceritakan proses pelaksanaan pembelajaran yang telah dilakukan maupun kesan-kesan dalam melaksanakan pembelajaran. Kesempatan berikutnya diberikan kepada anggota kelompok perencana yang dalam tahap do bertindak sebagai pengamat. Kritik dan saran disampaikan secara bijak tanpa 
merendahkan demi perbaikan untuk siklus berikutnya. Selain itu dilakukan diskusi dan pengkajian mengenai keefektifan pembelajaran yang telah dilakukan dan mencari solusi dari kelemahan pembelajaran. Adapun hal-hal yang direfleksi pada tahap see yaitu:

\section{a. Kesesuaian Pelaksanaan Pembelajaran dengan RPP}

Kegiatan pembelajaran yang ada di RPP dapat terlaksana dengan baik. Urutan kegiatan yang dilaksanakan sudah sesuai dengan yang dicantumkan dalam RPP. Waktu pelaksaan cukup sampai kegiatan penutup dan evaluasi serta pembahasan soal evaluasi.

\section{b. Partisipasi Peserta Didik dalam Pembelajaran}

Secara keseluruhan peserta didik terlihat aktif dan antusias untuk mengikuti pembelajaran. Pada saat kegiatan pembelajaran berlangsung Tema 8 Subtema 3 Pembelajaran 2, materi pokok kualitas air, hampir seluruh peserta didik aktif dalam kegiatan proses pembelajaran. Siswa aktif menjawab pertanyaan yang diajukan guru, siswa membantu guru membagikan LKPD serta membersihkan papan tulis. Siswa aktif mengumpulkan hasil evaluasi dengan tertib. Apabila ada peserta didik yang belum paham tentang materi yang dipelajari, maka guru memberikan instruksi untuk bertanya kepada teman dalam satu kelompok, apabila teman dalam satu kelompok tidak bisa memecahkan masalah maka boleh bertanya pada kelompok yang lain. Jika kelompok lain juga belum bisa menemukan solusi maka boleh bertanya kepada guru. Guru selalu melakukan pendekatan dan bimbingan apabila ada yang kesulitan. Dengan demikian, peserta didik tersebut mulai menunjukkan perhatian dan partisipasinya dalam kegiatan pembelajaran.

\section{c. Keberhasilan Keterampilan yang Dilatihkan}

Keterampilan peserta didik dalam memahami materi kualitas air sudah cukup baik. Hal ini terbukti selama kegiatan pembelajaran, peserta didik menunjukkan sikap antusias dalam proses pembelajaran berlangsung. Selain itu, keterampilan saat mengerjakan dan menjawab LKPD sudah cukup baik. Peran guru disini sebagai fasilitator yang memfasilitasi peserta didik dalam proses kegiatan pembelajaran.Berhasil dengan cara berkelompok.

\section{d. Kelemahan-kelemahan yang Dihadapi Adapun beberapa kelemahan}

yang dihadapi serta solusi yang disepakati Peseta didik dengan nama Fanny, Wahyudi, dan Mahesa terlihat kurang memperhatikan temannya yang sedang membaca. Dan juga saat kegiatan diskusi kelompok cenderung diam. solusi Guru menunjuk siswa yang kurang memperhatikan untuk selanjutnya membaca bagian cerita. Peserta didik menjawab pertanyaan guru dengan mengankat tangan dan ramai. solusi Guru menyuruh siswa untuk angkat tangan tanpa suara, guru selanjutnya memilih siswa yang paling cepat mengangkat tangan dengan tenang.

Berdasarkan data observer, cara guru menyajikan materi pokok pelajaran jelas dan teratur serta mudah dipahami. Selama pembelajaran guru memberikan pertnyaan kurang lebih 15 kali, serta memberikan kesempatan kepada seluruh siswa untuk menjawab. Ketika guru menjelaskan ada 2 siswa yang bertanya, kemudian guru membantu siswa yang kesulitan tersebut. Dalam pembelajaran tidak ada siswa yang mengganggu kelas. Suasana belajar siswa yang berhasil diciptakan guru terkendali dan kondusif. Berdasarkan hasil refleksi Lesson Study, guru model dan observer membuat kesepakatan, agar solusi yang telah diberikan bisa diterapkan kembali pada pembelajaran berikutnya. Selain itu, kelebihan yang sudah nampak harus dipertahankan dan dicoba untuk diterapkan di kelas lainnya.Sehinggakegiatan pembelajaran nantinya bisa berjalan dengan efektif dan efisien.

\section{Simpulan}

Dari Berdasarkan pelaksanaan pembela- jaran yang telah dilakukan, maka dapat disimpulkan bahwa pelaksanaan Lesson Study dengan menggunakan model pembelajaran Kooperatif AIR (Auditory, Intellectuallity, Repetition) menggunakan media power point pada materi pokok Kualitas Air berjalan dengan baik dan secara umum dapat membuat siswa belajar aktif. Namun ada beberapa kendala yang perlu diperbaiki ke depannya, antara lain sebagai berikut: 1) Ekspresi guru model agar lebih senyum, Penggunaan bahasa verbal lebih diperhatikan agar dapat memotivasi siswa dalam belajar dan berkompetisi positif, 3) Ada beberapa siswa yang terlihat tidak termotivasi dalam belajar, 4) Diperbanyak penjelasan dengan menulis keterangan di papan tulis. Kegiatan Lesson Study sebaiknya dilakukan pada pokok-pokok bahasan yang dianggap sulit oleh siswa. Kegiatan Lesson Study sebaiknya dilakukan secara.

\section{Daftar Pustaka}

Abdul Karim, Muchtar. 2006. Implementation Of Lesson Study For Improving The Quality Of Mathematics Instruction In Malang. Tsubaka Journal Of Educational Study In Mathematics, 45 
Akhmad Sudrajat. "Lessson Study Untuk Meningkatkan Proses Dan Hasil Pembelajaran”. Hlm 2, Dalam Http://Ideguru.Wordpress.Com/2010/ 04/09/Lesson-Study-Untuk- Meningkatkan-ProsesdanHasil- Pembelajaran/, Diakses Tanggal 1 April 2019

A.M Sadirman. 2004. Interaksi Dan Motivasi Belajar Mengajar. Jakarta: Rajawali Press.

Hendayana, S. Dkk. 2006. Lesson Study:Pengembangan Profesi Guru. Bandung: Rizky Press

Indriati (2012) 'Jurnal Pendidikan Ipa Indonesia Pembelajaran Science-Edutainment Berbantuan Media', 1(2), Pp. 192-197.

Herawati. Chotimah, Husnul. Joharmawan, Ridwan. Jumiati. Sari, Yuyun D. Sunarjo. 2011. Lesson Study Berbasis Sekolah. Malang: Universitas Negeri Malang

Novianti, Y. (2020) 'Melalui Penggunaan Media Kartu Gambar Pada Siswa Kelas Vii Smpn 1 Muara Bungo', 5(1), Pp. 551-556.

Syamsiara Nur, S. P. (2017) 'Efektivitas Model Problem Based Learning (Pbl) Terhadap Hasil Belajar Mahasiswa Prodi Pendidikan Biologi Universitas Sulawesi Barat', 2(2), Pp. 133-141. Doi: 10.31219/Osf.Io/378f2.

Wardana, A. E. (2020) 'Partisipasi Aktif Siswa Fpips , Ikip Pgri Bojonegoro Fpips , Ikip Pgri Bojonegoro Fpmipa , Ikip Pgri Bojonegoro Pendahuluan Perubahan Kurikulum Berbasis Kurikulum Isi Ke Dari Menjadi Manusia Yang Beriman Dan Bertaqwa Kepada Tuhan Yang Maha Esa , Berakhlak', Jurnal Pendidikan Edutama, 1 No 1, Pp. 1-11. 